University of New Mexico

UNM Digital Repository

Biology ETDs

Electronic Theses and Dissertations

5-1-2015

\title{
The indirect effects of climate variability on the reproductive dynamics and productivity of an avian predator in the arid southwest
}

Corrie C. Borgman

Follow this and additional works at: https://digitalrepository.unm.edu/biol_etds

Part of the Biology Commons

\section{Recommended Citation}

Borgman, Corrie C.. "The indirect effects of climate variability on the reproductive dynamics and productivity of an avian predator in the arid southwest." (2015). https://digitalrepository.unm.edu/biol_etds/8

This Thesis is brought to you for free and open access by the Electronic Theses and Dissertations at UNM Digital Repository. It has been accepted for inclusion in Biology ETDs by an authorized administrator of UNM Digital Repository. For more information, please contact disc@unm.edu. 
Corrie C. Borgman

Candidate

Biology

Department

This thesis is approved, and it is acceptable in quality and form for publication:

Approved by the Thesis Committee:

Blair O. Wolf, Chairperson

Seth D. Newsome

Scott L. Collins 
THE INDIRECT EFFECTS OF CLIMATE VARIABILITY ON THE REPRODUCTIVE DYNAMICS AND PRODUCTIVITY OF AN AVIAN PREDATOR IN THE ARID SOUTHWEST

By

CORRIE C. BORGMAN

B.S., BIOLOGY, UNIVERSITY OF NEW MEXICO, 2001

\section{THESIS}

Submitted in Partial Fulfillment of the

Requirements for the Degree of

\section{Master of Science}

Biology

The University of New Mexico

Albuquerque, New Mexico

May 2015 


\section{ACKNOWLEDGEMENTS}

This project was made possible only through the continued funding and support of the Department of Defense and Kirtland Air Force Base. Many thanks to Carol Finley and Dustin Akins, Natural Resource Managers at Kirtland AFB for all of their help. Additionally, staff and friends at Envirological Services, Inc. provided invaluable support. Victoria Bailey and Ken Babcock tirelessly helped collect this data for the duration of this project, and without them this project would not have been possible. Kirsten Cruz-McDonnell, Octavio Cruz-Carretero and Marianne Wootten provided indispensable assistance in many ways, from logistical support to field assistance to analysis and moral support. A very special thanks to my boss, Marianne Wootten, for not only granting me the flexibility to develop this project, but also for allowing me to use it to pursue this degree.

Many people offered assistance with program MARK: Hillary White, Jenny Davis, and Dr. Mark Gould provided much appreciated help. Dr. Blair Wolf and my other committee members, Dr. Seth Newsome and Dr. Scott Collins, provided guidance for this and many other projects, and their experience and knowledge has helped me grow as a biologist and student.

I'd also like to thank my parents for their support in my career path. Many years were spent in the field under a vast number of projects and supervisors, across the United States and beyond. These experiences not only taught me much about biology, but also about the spectacle of nature, life and the world. The people who affected my life through this are too innumerable to list. 


\title{
THE INDIRECT EFFECTS OF CLIMATE VARIABILITY ON THE REPRODUCTIVE DYNAMICS AND PRODUCTIVITY OF AN AVIAN PREDATOR IN THE ARID SOUTHWEST
}

\author{
By \\ Corrie C. Borgman \\ B.S., Biology, University of New Mexico, 2001 \\ M.S., Biology, University of New Mexico, 2015
}

\begin{abstract}
The deserts of the Southwestern United States are experiencing rapid warming and climate models predict declining winter precipitation. The combined effects of higher air temperatures and drought are a reduction in productivity, which may importantly impact reproduction in consumers. Here, we investigate the effects of warming and drought on the reproductive timing and output in loggerhead shrikes (Lanius ludovicianus) in central New Mexico from 2007 to 2012. We found increases in air temperature of $3^{\circ} \mathrm{C}$ during the breeding season (March - July) and highly variable winter and annual precipitation. With increasing spring temperatures, shrikes advanced nesting phenology by 20 days over 6 years, a much higher rate than is reported for any other bird species. During this period, the number of breeding pairs also increased from 25 to 37 , and clutch size and the number offspring produced per successful nest did not vary. Nest success, however, was often very low and ranged from $11 \%$ to $44 \%$. Although our
\end{abstract}


models indicated that low nest success was driven by precipitation and temperature, it was mediated indirectly through increased predation rates during the hot and dry periods. 


\section{TABLE OF CONTENTS}

LIST OF FIGURES......................................................................................................iii

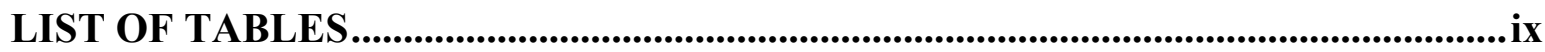

INTRODUCTION ........................................................................................................................

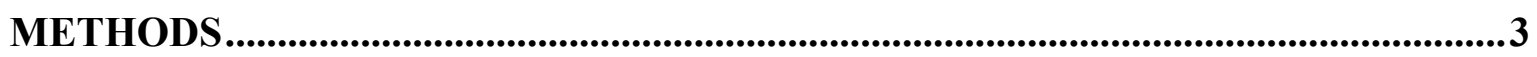

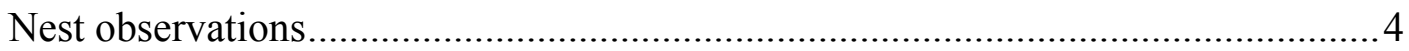

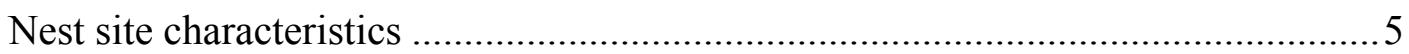

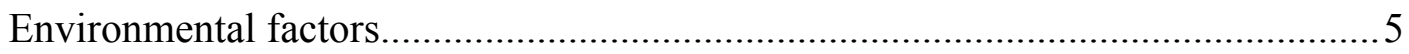

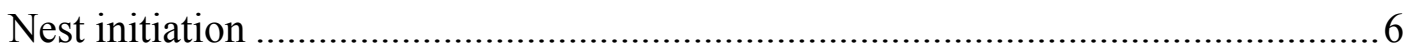

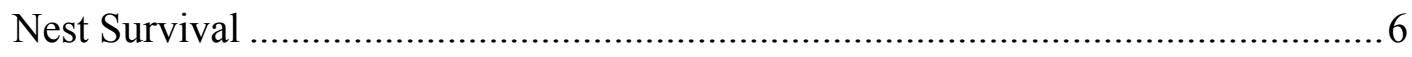

Statistical Analysis ..................................................................................

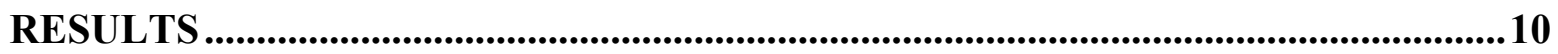

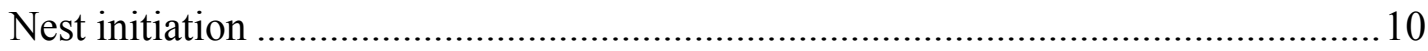

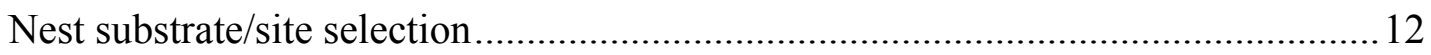

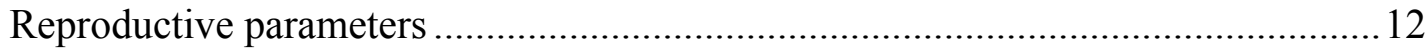

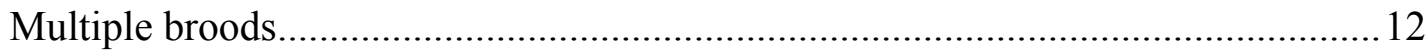

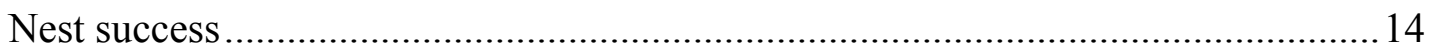

Overall productivity metrics ................................................................................. 18

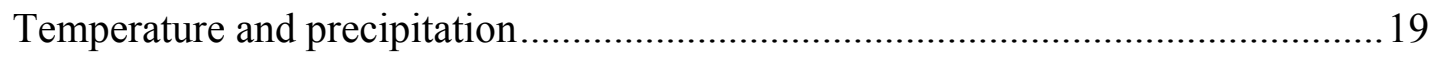

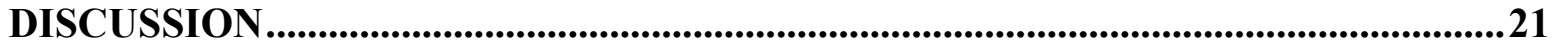

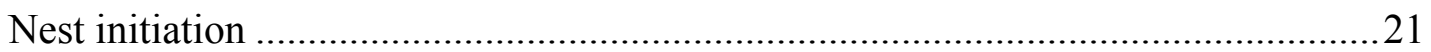

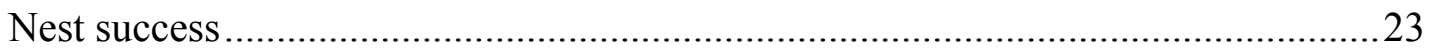

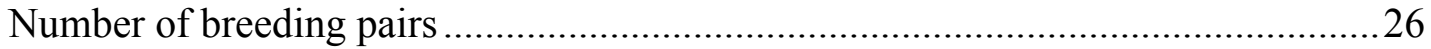




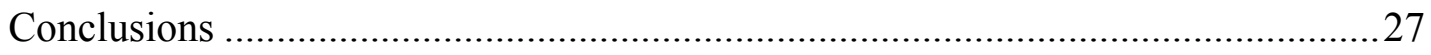

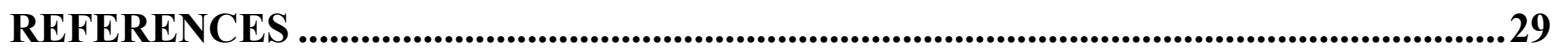




\section{LIST OF FIGURES}

Figure 1. Mean estimated Loggerhead shrike nest initiation dates and associated March April mean maximum temperatures from 2007 to 2012. Mean initiation dates are indicated as approximate corresponding dates to Julian days.

Figure 2. Linear model of program MARK nest success estimates and winter precipitation for Loggerhead shrikes nesting on Kirtland Air Force Base, NM from 20072012. MARK nest success was estimated by applying annual daily survival rates to the average length of the nesting period (34 days). The solid line indicates the line of best fit

for the model and dotted lines represent $95 \%$ confidence intervals. 16

Figure 3. Nest daily survival rates estimated from the highest supported model from program MARK over the course of the breeding period (2007-2012) for Loggerhead shrikes nesting on Kirtland Air Force Base, NM. Day 1 of the nesting season corresponds to March 7, and spanned 147 days for the entire study period. Error bars represent 95\% confidence intervals.

Figure 4. Number of breeding Loggerhead shrike pairs between 2007 and 2012 on Kirtland Air Force Base, NM and breeding season temperature $\left({ }^{\circ} \mathrm{C}\right)$. 19 


\section{LIST OF TABLES}

Table 1. Clutch size by brood, hatching success, and number fledged by brood for Loggerhead shrikes breeding on Kirtland Air Force Base, New Mexico between 2007 and 2012.

Table 2. Summary of Loggerhead shrike breeding pairs and nest success and nests lost to predation on Kirtland Air Force Base between 2007 and 2012. Nest success from both Mayfield and MARK estimates are given; MARK estimates are based on the constant survival model.

Table 3. Tested models of daily survival rate of Loggerhead shrikes on Kirtland Air Force Base, Albuquerque, NM, from 2007 - 2012. Models are ranked by $\triangle \mathrm{AICc}$. Variables included in models are: winter precipitation recorded between December and March (Winter Precip.), active period precipitation recorded during each nest's active period (Active Precip.), breeding season temperature, recorded between March and July (BSTEMP), mean maximum temperature recorded during each nest's active period (MMXT), nest concealment (Conceal) and nest height (Nest Ht.). Temporal trends are denoted " $\mathrm{T}$ " for a linear trend over time and "TT" for a quadratic trend.

Table 4. Annual and winter precipitation and mean annual and breeding season temperature for Albuquerque International Airport (distance from study area). Winter precipitation was recorded between December of previous year and January - March of 
year indicated. Breeding season temperatures are the mean of March - July temperatures

and spring temperatures are recorded from March - April. ............................................20 


\section{Introduction}

Warming climates have led to earlier phenology of diverse organisms (Parmesan and Yohe 2003; Root et al. 2003), but differential shifts in phenology between consumers and their prey can yield mismatched timing and impact reproductive success (Both et al. 2006; Saino et al. 2011). Yet, phenological shifts may not always yield mismatched timing and instead may reflect adaptive plasticity (Charmantier et al. 2008; Dunn et al. 2011; Martin 2007). Of course, climate change may also impact reproductive output by changing primary productivity and food availability or intensity of predation pressure (Martin 2007; McShea 2000). Thus, the demographic impacts of climate change and phenological shifts are unclear and need further study.

Most research has keyed on the reproductive activities of animals in wet temperate climates and our understanding of how warming affects reproductive success and phenology of birds in hot arid systems is poorly known (but see Bolger et al. 2005; Brown et al. 1999; Li and Brown 1999). Yet, climate change and its demographic consequences may be particularly severe in desert regions. For example, the southwestern United States is a region that has recently been subject to rising air temperatures and increasingly severe droughts associated with decreased precipitation. Air temperatures in the arid southwestern United States may warm by $4-6^{\circ} \mathrm{C}$ over the next century and precipitation regimes are expected to become less reliable, with less overall and winter precipitation (Romero-Lankao et al. 2014). Deserts define much of this landscape and resources such as water and energy are often in short supply. Because the productivity of deserts are defined by water (Noy-Meir 1973), the combined effects of increasing air temperatures and decreasing precipitation may well have disastrous effects 
on secondary productivity. For breeding birds, food can be important to reproductive output and survival (Martin 1987) such that reduced primary productivity and harsher physical conditions may have effects on adult condition and survival (McKechnie and Wolf 2010) as well as reproductive effort and success (Bolger et al. 2005). Given the challenges that are already inherent to these ecosystems, understanding the effects of additional physical and ecological stress on animal reproductive activity is likely to provide important insights into the limits of performance and the resilience of desert birds in future climates and ecosystems.

The loggerhead shrike (Lanius ludovicianus) is an aggressive, medium-sized predatory bird that occupies open habitats ranging from southern Canada to central Mexico. Despite its' extensive distribution, shrike populations have declined dramatically over the last 40 years; North American Breeding Bird Survey estimates indicate that continentally, populations have decreased by as much as $79 \%$ (Sauer et al. 2014). The potential contribution of climate change to this serious population decline has not been examined, and populations in the arid southwest are particularly understudied.

Given long-term trends towards a hotter and drier environment in the desert southwest, we studied shrike breeding output and quantified reproductive success in this environment. We conducted our studies during a period of rapid warming at a site where land use changes have been relatively static, but temperature and precipitation were highly variable. We asked the following questions: 1) has recent warming advanced reproductive activity? 2) has number of breeding pairs declined with higher air temperatures and drought as might be expected due to decreased production of insect and vertebrate prey resources? 3) have metrics of productivity (clutch size, number of young 
fledged) been impacted by higher air temperatures and drought? We then used the answers to these questions to model how nest success responded to environmental variables such as various periods of precipitation and breeding season temperatures, as well as nest site variables such as nest height and concealment, and time of the season.

\section{Methods}

From 2007 through 2012 we studied a population of Loggerhead shrikes on Kirtland Air Force Base (KAFB), located directly south of Albuquerque, New Mexico. A semi-arid environment, habitat is characterized by desert grassland, plain-mesa sand scrub, and juniper savanna (Dick-Peddie 1993). Predominant tree and shrub species include four-wing saltbush (Atriplex canescens), one-seeded juniper (Juniperus monosperma), and Siberian elm (Ulmus pumilla). The understory is comprised of various grasses including Aristida spp., Sporobolus crypfandrus, Hilaria jamesii, and Hesperostipa neomexicana. The study area covers approximately 15,000 ha at an elevation of around 1,620 m. Urban development such as base housing, the airport, and other buildings on the base are concentrated at the north end of the base where it borders Albuquerque. Elsewhere, structures are sparsely distributed across the study area. These isolated structures are typically surrounded by native habitat.

The Albuquerque International Airport, which directly borders the north end of the study area, receives $240.5 \mathrm{~mm}$ of precipitation annually. The timing of precipitation in this region is bimodal with approximately half of the rainfall in the winter months and half during summer monsoon. Mean temperatures during the breeding season range from $8.9^{\circ} \mathrm{C}$ in March to $25.8^{\circ} \mathrm{C}$ in July. As a result of increased greenhouse gases, 
temperatures in the southwestern United States are expected to increase at least $2-4^{\circ} \mathrm{C}$ by 2100 (Romero-Lankao et al. 2014). In particular, winters are expected to be warmer with less precipitation. Lower snowpack, earlier snowmelt, reduced available groundwater, potential prolonged droughts, and extreme precipitation events are expected in New Mexico (Romero-Lankao et al. 2014; State of New Mexico 2005). During our study period, spring maximum temperatures increased $3^{\circ} \mathrm{C}$, breeding season mean temperatures increased $2^{\circ} \mathrm{C}$, and annual mean temperatures increased $1.4^{\circ} \mathrm{C}$.

Precipitation was highly variable, but was below average in most years, and winter precipitation was also limited in most years.

\section{Nest Observations}

From 2007 - 2012, we located adult Loggerhead shrikes along roadsides or in historic nest territories. Each year surveys began at the beginning of March and continued until breeding ceased (generally early to mid-July). Surveyor effort and areas surveyed were consistent throughout the study period. Two to three observers conducted surveys five days a week. The same two individuals conducted surveys over the six-year period; one additional observer was present in 2009, 2010 and 2011. We determined nest locations by observing parental behaviors or by systematically searching areas where breeding activities were observed. After discovery, nest contents were checked every 3 4 days. From nest observations, we were able to determine clutch size, proportion of eggs that hatched, number of young fledged per successful nest, total number of pairs, total nesting attempts and nest success. Nests were considered successful if $\geq 1$ young fledged. 


\section{Nest Site Characteristics}

Following cessation of breeding activity, we measured nest site characteristics. We recorded nest substrate species, nest height and nest concealment. Nest concealment was established by estimating the percentage of a $10 \mathrm{~cm}$ diameter circle in the position of the nest that would be concealed by the nesting substrate. Four measurements were taken, one from each cardinal direction, from $1 \mathrm{~m}$ high and $1 \mathrm{~m}$ from the nest and were averaged for total estimated nest concealment.

\section{Environmental Factors}

Precipitation and temperature measurements were obtained from the Albuquerque International Airport $\left(35.042^{\circ} \mathrm{N}, 106.616^{\circ} \mathrm{W}\right)$, provided by the National Oceanic and Atmospheric Administration National Climatic Data Center (www.ncdc.noaa.gov). To test the effects of temperature and precipitation on various productivity metrics, we considered these measures over various biologically relevant time periods. We evaluated precipitation annually and for winter months prior to breeding (December - March) as well as active period daily precipitation. Active period daily precipitation was calculated as the sum of daily precipitation that was recorded during the period that a single nest was active. Mean and mean maximum temperatures were considered annually, for the period during and prior to nest initiation (March - April), and for the breeding season (March - July). 


\section{Nest Initiation}

Nest initiation dates were determined from nest content observations such as date of first egg whenever possible. More frequently, however, initiation dates were estimated from known nestling ages and fledge dates. Nests that were discovered after a full clutch had been laid but failed before hatching were eliminated from the sample. Initiation dates were considered as the date the first egg was laid.

\section{Nest Survival}

We define nest survival as the probability that a nest survived a one-day period. Nest success refers to nest survival over the entire nesting period, which on average was 34 days. Daily nest survival was established using program MARK (White and Burnham 1999). In MARK, robust estimates of survival can be obtained, and covariates and their importance in driving nest survival can also be established (Jehle et al. 2004; Rotella et al. 2000). Covariates can include those for individual nest sites, such as habitat features, and group and time-specific variables such as environmental variables.

\section{$\underline{\text { Statistical Analysis }}$}

With the exception of nest survival, all statistical analyses were conducted using $\mathrm{R}$ version 3.0.2 (R Core Team 2013). All tests were evaluated at an alpha level of 0.05, and values are reported as means $\pm 95 \%$ confidence intervals. 


\section{Nest Initiation}

We used a one-way ANOVA's to test if mean nest initiation dates differed significantly over the six years of study and to test whether mean Julian nest initiation date of first broods differed according to mean maximum temperature for the month of March and April. Most first broods were initiated within this time period for all years of study, therefore we hypothesized that higher temperatures during this period would result in earlier nest initiation. Mean maximum temperatures for the months of March and April ranged from $18.06^{\circ} \mathrm{C}$ in 2007 to $21.11^{\circ} \mathrm{C}$ in 2012 ; the long-term average is $19.39^{\circ} \mathrm{C}$ (Table 4). Temperatures were separated into four categories evenly divided between 18 and $22^{\circ}$ C. Low (18.01-19.0), medium-low (19.01-20.0), medium-high (20.01-21.0), and high (21.01-22.0). Temperatures during the study period never fell in the medium-high category; therefore only three categories were tested. For both of these tests, data were log transformed to meet assumptions of normally distributed residuals and multiple comparisons were conducted post hoc using the Tukey HSD test.

\section{Productivity}

We tested if annual mean clutch size and number of young fledged per successful nest differed between years using a Kruskal-Wallis ANOVA. We used Mann-Whitney two sample procedures with an adjusted error rate of 0.0083 for pairwise comparisons. Wilcoxon two-sample procedures were used to test for differences in clutch size and number of young fledged between broods as well differences in the number of days and distance between first and second broods based on the fate of the initial brood. We evaluated the relationship between environmental and productivity metrics using multiple 
linear regressions. Total number of pairs and estimated eggs laid were used as metrics for productivity. Breeding season temperature, winter precipitation, and March-April mean maximum temperatures were used as environmental metrics. Model selection was based on minimum $R^{2}$ and BIC values.

\section{Nest Survival}

We evaluated nest survival using program MARK. Model selection was based on AIC corrected for small sample size $\left(\mathrm{AIC}_{\mathrm{c}}\right.$; Akaike 1973; Anderson et al. 1998). The model with the lowest $\Delta \mathrm{AIC}_{\mathrm{c}}$ is considered the best-approximating model, given the data (Anderson et al. 1998; Jehle et al. 2004). $\operatorname{AIC}_{\mathrm{c}}$ weights $\left(w_{\mathrm{i}}\right)$ are also useful in evaluating model strength, with smaller $\mathrm{w}_{\mathrm{i}}$ values indicating decreased plausibility that the selected model is the actual best model (Anderson et al. 1998). We considered a number of a priori models that we hypothesized would be important in determining nest survival. These included:

1. Time effects: constant, linear, and quadratic time effects were examined.

2. Environmental factors prior to or during the breeding season that were constant for the whole group. These were winter precipitation (Winter Precip.; DecemberMarch) and mean breeding season temperature (BSTEMP; March-July). We hypothesize that increased winter precipitation should positively impact daily survival rate (DSR) as plant production and arthropod abundance and biomass are positively correlated with precipitation (Bolger et al. 2005; Muldavin et al. 2008; Tanaka and Tanaka 1982). Increased breeding season temperature is expected to have a negative impact on DSR as increased temperatures may cause 
physiological stress to breeding adults and growing nestlings (Cunningham et al. 2013).

3. Environmental factors at individual nests. These variables were calculated for the period during which a nest was active, i.e. from nest initiation through cessation. These include the active period precipitation (Active Precip.) received and mean maximum temperature (MMXT). We hypothesize again that the total precipitation received should positively influence plant health and food availability and thus nest survival. Additionally, nest predation rates may be higher during times of reduced precipitation (Martin 2007). Mean maximum temperature is expected to influence DSR similarly to breeding season temperature. DSR at nests subjected to higher daily temperatures may be negatively impacted due to stresses associated with heat.

4. Characteristics of individual nest sites. Factors such as nest height (Nest Ht.) and nest concealment (Conceal.) have been implicated by other studies as influential in determining nest survival (Martin and Roper 1988; Porter et al. 1975; Yosef 1996). Increased nest concealment should increase DSR, as certain predators, such as those that hunt by sight, should less easily detect more concealed nests. However, concealment may not be an important factor in deterring predators that hunt via olfaction. Nest height may deter mammalian predators such as coyotes. However, these factors may not be influential in deterring predators that hunt from above or those that are efficient climbers. 
Model selection occurred by first evaluating basic time and group trends. These included: constant survival, year effect, and linear and quadratic time trends (T and TT, respectively). Of these, the model with the greatest support was selected and environmental covariates that were applied to entire groups were added. Individual covariates were added singly to the model receiving greatest support. If additional parameters resulted in $\triangle \mathrm{AIC}$ of $>2$, we also evaluated Akaike weights for model strength.

\section{Results}

\section{Nest Initiation date}

Nest initiation Julian day was estimated for 147 nests over six years of study. For all years, nests were initiated between March 7 and June 29. Mean Julian initiation day for all years was 117.4, corresponding to April 27-28. Mean initiation dates were 20 days earlier in 2012 than in 2007 (Figure 1), and earliest nests were 28 days earlier in 2012 than 2007. 
Figure 1. Mean estimated Loggerhead shrike nest initiation dates and associated March April mean maximum temperatures from 2007 to 2012. Mean initiation dates are indicated as approximate corresponding dates to Julian days.

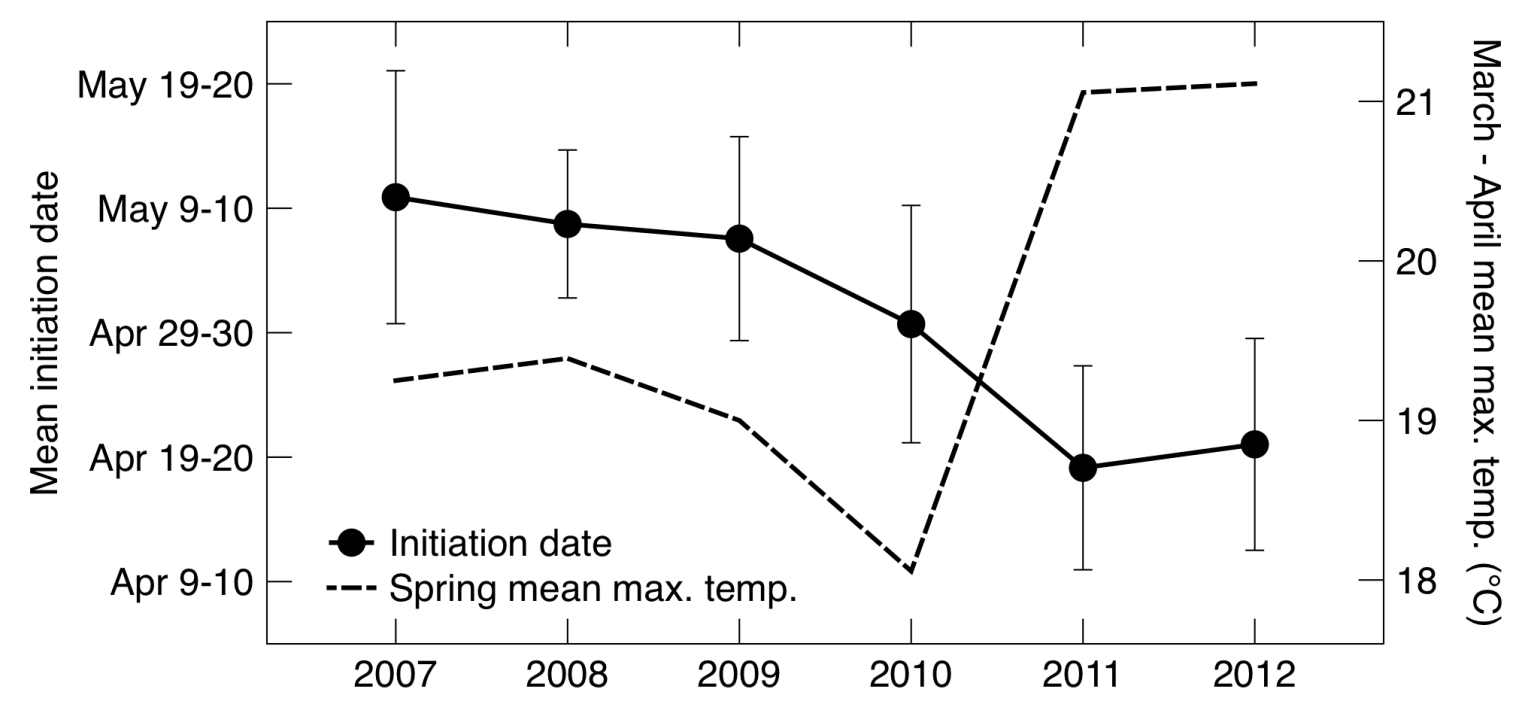

Mean initiation dates differed significantly over the six years of study $\left(\mathrm{F}_{5,164}=\right.$ 5.55, $P<0.001)$. Mean initiation dates in $2007-2009$ were significantly later than mean initiation dates in 2011 and 2012. Mean initiation dates in 2010 were intermediate between the group $2007-2009$ and $2011-2012$ and did not significantly differ from either group.

The results of a one-way ANOVA show significantly different nest initiation dates for first broods based on March - April mean maximum temperatures $\left(\mathrm{F}_{2,108}=\right.$ $21.11, P<0.001)$. Pairwise comparisons show no difference in initiation dates between the low and medium-low temperature groups $(P=0.32)$. However, initiation dates were significantly earlier in the high temperature group than either the low or medium-low temperature groups (both groups, $P<0.001$ ). 


\section{Nest Substrates/Site Selection}

We located 187 Loggerhead shrike nests in fifteen different substrates over the entire study period. Four-wing saltbush $(n=94)$, one-seeded juniper $(n=37)$, Siberian elm $(n=33)$ and tree cholla (Cholla spp., $n=9)$ were most frequently used. Nest height ranged from 0.4 to $6.5 \mathrm{~m}$, mean nest height was $1.1 \pm 0.1 \mathrm{~m}(n=171)$. Mean nest substrate height was $3.0 \pm 0.4 \mathrm{~m}$ and ranged from 1.0 to $13.2 \mathrm{~m}(n=175)$. Annual average nest concealment for all years was $82 \%$ and ranged from 74 to $92 \%$.

\section{Reproductive Parameters}

Clutch size ranged from three to seven eggs; mean clutch size for all years was $5.35 \pm 0.15$ eggs (Table 1). Clutch size distributions varied across years (Kruskal-Wallis $\left.\mathrm{X}^{2}=18.17, \mathrm{df}=5, P=0.003\right)$. Only clutch sizes in 2009 and 2012 differed significantly from one another (Wilcoxon two-sample $\mathrm{W}=460.5, P=0.002)$. Mean proportion of eggs that hatched was $59.69 \%$ and ranged from $51.73 \%$ to $66.36 \%$. Successful nests fledged between one and seven young, and averaged $4.55 \pm 0.36$ young over all years. Number of young fledged per year did not differ $\left(\mathrm{X}^{2}=6.99, \mathrm{df}=5, P=0.22\right)$.

\section{Multiple broods}

Clutch sizes did not differ between first and second broods (Table 1, $\mathrm{W}=1602, P$ $=0.40$ ) when considering all years together. When years were considered individually, only clutches in 2007 differed in size between broods $(\mathrm{W}=85, P=0.02)$. Number of young fledged also did not differ between first and second broods ( $\mathrm{W}=427, P=0.38)$. Mean number of days between broods was $13.1 \pm 2.3$ days for all years. Timing between 
broods did not vary between the two hottest years (2011 and 2012) and other years ( $\mathrm{W}=$ $157, P=0.91$ ), though temperatures were above long-term averages in all years. Mean distance between first and second brood locations was $193.1 \pm 48.9 \mathrm{~m}$. There was no significant difference in time between broods depending on fate of the initial clutch ( $W=$ $101, P=0.20)$. Second broods were significantly further from the initial nest location when the first brood failed $(W=279.5, P=0.03)$.

Table 1. Clutch size by brood, hatching success, and number fledged by brood for Loggerhead shrikes breeding on Kirtland Air Force Base, New Mexico between 2007 and 2012.

\begin{tabular}{|c|c|c|c|c|c|c|c|}
\hline \multirow[t]{2}{*}{ Year } & \multicolumn{3}{|c|}{ Clutch size } & \multirow{2}{*}{$\begin{array}{l}\text { Percent } \\
\text { eggs } \\
\text { hatched }\end{array}$} & \multicolumn{3}{|c|}{$\begin{array}{c}\text { Number fledged per successful } \\
\text { nest }\end{array}$} \\
\hline & $\begin{array}{c}1 \text { st } \\
\text { brood }\end{array}$ & $\begin{array}{l}\text { 2nd } \\
\text { brood }\end{array}$ & Total & & $\begin{array}{c}1 \text { st } \\
\text { brood }\end{array}$ & $\begin{array}{l}\text { 2nd } \\
\text { brood }\end{array}$ & Total \\
\hline 2007 & $\begin{array}{l}5.4 \pm 0.4 \\
(n=15)\end{array}$ & $\begin{array}{c}4.4 \pm 0.7 \\
(n=7)\end{array}$ & $\begin{array}{c}5.1 \pm \\
0.4 \\
(\mathrm{n}=22)\end{array}$ & $60 \%$ & $\begin{array}{l}5.1 \pm 0.7 \\
(n=13)\end{array}$ & $\begin{array}{c}2.7 \pm 2.9 \\
(n=3)\end{array}$ & $\begin{array}{c}4.6 \pm \\
0.8 \\
(n=16)\end{array}$ \\
\hline 2008 & $\begin{aligned} 5.0 & \pm 0.8 \\
(n & =9)\end{aligned}$ & $\begin{array}{c}4.5 \pm 6.4 \\
(n=2)\end{array}$ & $\begin{array}{c}4.9 \pm \\
0.6 \\
(n=11)\end{array}$ & $54 \%$ & $\begin{aligned} 3.8 & \pm 2.0 \\
(n & =5)\end{aligned}$ & $\begin{aligned} 3.0 & \pm 2.5 \\
(n & =3)\end{aligned}$ & $\begin{array}{c}3.5 \pm \\
1.2 \\
(n=8)\end{array}$ \\
\hline 2009 & $\begin{array}{l}5.0 \pm 0.5 \\
(n=15)\end{array}$ & $\begin{array}{c}5.2 \pm 0.6 \\
(n=5)\end{array}$ & $\begin{array}{c}5.0 \pm \\
0.4 \\
(n=21)\end{array}$ & $66 \%$ & $\begin{array}{c}4.5 \pm 6.4 \\
(n=2)\end{array}$ & $\begin{array}{c}3.0 \pm \\
\text { NA } \\
(n=1)\end{array}$ & $\begin{array}{c}4.0 \pm \\
2.5 \\
(n=3)\end{array}$ \\
\hline 2010 & $\begin{array}{l}5.8 \pm 0.3 \\
(n=12)\end{array}$ & $\begin{aligned} 5.5 & \pm 0.9 \\
(n & =6)\end{aligned}$ & $\begin{array}{c}5.6 \pm \\
0.3 \\
(n=19)\end{array}$ & $52 \%$ & $\begin{array}{c}5.1 \pm 0.6 \\
(n=7)\end{array}$ & $\begin{aligned} 5.0 & \pm 4.3 \\
(n & =3)\end{aligned}$ & $\begin{array}{c}5.1 \pm \\
0.7 \\
(n=10)\end{array}$ \\
\hline 2011 & $\begin{array}{l}5.5 \pm 0.3 \\
(n=17)\end{array}$ & $\begin{array}{c}5.0 \pm 1.3 \\
(n=8)\end{array}$ & $\begin{array}{c}5.4 \pm \\
0.4 \\
(n=26)\end{array}$ & $59 \%$ & $\begin{array}{l}4.9 \pm 0.5 \\
(n=14)\end{array}$ & $\begin{array}{c}3.0 \pm \\
\mathrm{NA} \\
(n=1)\end{array}$ & $\begin{array}{c}4.8 \pm \\
0.5 \\
(n=15)\end{array}$ \\
\hline 2012 & $\begin{array}{l}5.6 \pm 0.4 \\
(n=22)\end{array}$ & $\begin{array}{c}5.9 \pm 0.7 \\
(n=8)\end{array}$ & $\begin{array}{c}5.7 \pm \\
0.3 \\
(n=30)\end{array}$ & $66 \%$ & $\begin{array}{c}3.9 \pm 1.5 \\
(n=8)\end{array}$ & $\begin{array}{c}5.3 \pm 1.8 \\
(n=7)\end{array}$ & $\begin{array}{c}4.5 \pm \\
1.1 \\
(n=15)\end{array}$ \\
\hline Average & $\begin{array}{l}5.4 \pm 0.2 \\
(n=90)\end{array}$ & $\begin{array}{l}5.3 \pm 0.3 \\
(n=35)\end{array}$ & $\begin{array}{c}5.4 \pm \\
0.2 \\
(n= \\
128)\end{array}$ & $60 \%$ & $\begin{array}{l}4.7 \pm 0.4 \\
(n=49)\end{array}$ & $\begin{array}{l}4.2 \pm 0.9 \\
(n=18)\end{array}$ & $\begin{array}{c}4.6 \pm \\
0.4 \\
(n=67)\end{array}$ \\
\hline
\end{tabular}




\section{Nest Success}

Program MARK nest success estimates ranged from 12\% in 2009 to $44 \%$ in 2007. We include Mayfield nest success (Mayfield 1961; Mayfield 1975) estimates for comparison (Table 2), but analysis was performed on MARK estimates. Mean success was 30\% for all years combined. Over all years, 39\% of nests fledged, and nests were lost most frequently to predation (43\%), abandonment (10\%), weather (primarily wind storms, $2 \%$ ), and failure of eggs to hatch (1\%). We were unable to determine the cause of nest failure in $4 \%$ of cases due to insufficient evidence or inaccessibility of nest sites. 
Table 2. Summary of Loggerhead shrike breeding pairs and nest success and nests lost to predation on Kirtland Air Force Base between 2007 and 2012. Nest success from both Mayfield and MARK estimates are given; MARK estimates are based on the constant survival model.

\begin{tabular}{|c|c|c|c|c|c|c|}
\hline Year & $\begin{array}{l}\text { Number } \\
\text { breeding } \\
\text { pairs }\end{array}$ & $\begin{array}{c}\text { Number } \\
\text { breeding } \\
\text { pairs with }> \\
1 \text { brood }\end{array}$ & $\begin{array}{c}\text { Number } \\
\text { successful second } \\
\text { broods }\end{array}$ & $\begin{array}{c}\text { MARK Nest } \\
\text { Success Estimate }\end{array}$ & $\begin{array}{l}\text { Mayfield Nest } \\
\text { Success }\end{array}$ & $\begin{array}{c}\text { Nests lost to } \\
\text { predation }\end{array}$ \\
\hline 2007 & 29 & 10 & 3 & $44 \%$ & $47 \pm 4 \%$ & $23 \%$ \\
\hline 2008 & 25 & 6 & 3 & $28 \%$ & $33 \pm 6 \%$ & $35 \%$ \\
\hline 2009 & 25 & 5 & 1 & $12 \%$ & $11 \pm 3 \%$ & $73 \%$ \\
\hline 2010 & 27 & 8 & 3 & $33 \%$ & $30 \pm 5 \%$ & $46 \%$ \\
\hline 2011 & 32 & 10 & 1 & $30 \%$ & $27 \pm 4 \%$ & $37 \%$ \\
\hline 2012 & 37 & 11 & 7 & $35 \%$ & $35 \pm 4 \%$ & $44 \%$ \\
\hline $\begin{array}{c}\text { Mean all } \\
\text { years }\end{array}$ & 29.2 & 8.3 & 2.8 & $30 \%$ & $31 \pm 2 \%$ & $43 \%$ \\
\hline
\end{tabular}


Linear regressions were conducted on the relationship between nest success and temperature and precipitation variables (annual and winter precipitation; annual and breeding season mean temperatures). A significant positive relationship was found $\left(r^{2}=\right.$ $0.66, P=0.05$ ) between winter precipitation and nest success (Figure 2). No significantrelationships exist between nest success and annual precipitation, mean annual temperature, or mean breeding season temperature.

Figure 2. Linear model of program MARK nest success estimates and winter precipitation for Loggerhead shrikes nesting on Kirtland Air Force Base, NM from 20072012. MARK nest success was estimated by applying annual daily survival rates to the average length of the nesting period ( 34 days). The solid line indicates the line of best fit for the model and dotted lines represent $95 \%$ confidence intervals.

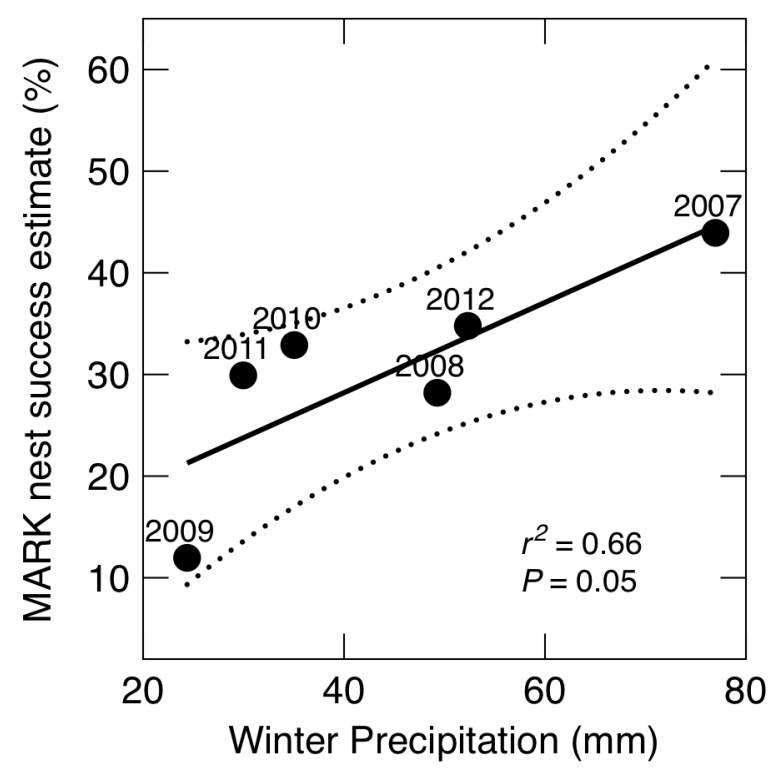

The program MARK models with greatest support showed that nest survival for loggerhead shrikes was driven by time of the nesting season, winter precipitation, active period precipitation and mean maximum temperature during the active nest period for any given nest (Table 3). Nest survival decreased over the course of the season (Figure 
3). Winter precipitation, active period precipitation, and mean maximum temperature all had a positive effect on nest survival. Models that included breeding season temperature, nest height or nest concealment did not add support to the model. In models where nest height or concealment were included, $\Delta \mathrm{AIC}$ values were $<2$. Because the penalty for an added parameter is 2 AIC points, these parameters can be interpreted as adding no additional support to the model and should be ignored (Arnold 2010). When the models including concealment or nest height are removed, the AIC weight $\left(w_{\mathrm{i}}\right)$ for the best model is $>0.99$, which gives strong support that this model best represents our data.

Table 3. Tested models of daily survival rate of Loggerhead shrikes on Kirtland Air Force Base, Albuquerque, NM, from 2007 - 2012. Models are ranked by $\triangle$ AICc. Variables included in models are: winter precipitation recorded between December and March (Winter Precip.), active period precipitation recorded during each nest's active period (Active Precip.), breeding season temperature, recorded between March and July (BSTEMP), mean maximum temperature recorded during each nest's active period (MMXT), nest concealment (Conceal) and nest height (Nest Ht.). Temporal trends are denoted " $\mathrm{T}$ " for a linear trend over time and "TT" for a quadratic trend.

\begin{tabular}{|c|c|c|c|c|c|}
\hline Model & $\mathrm{AICc}$ & $\triangle \mathrm{AICc}$ & $w_{\mathrm{i}}$ & $\mathrm{K}$ & Deviance \\
\hline $\begin{array}{c}\mathrm{T}+\text { Winter Precip. }+ \text { Active Precip. }+ \\
\text { MMXT }\end{array}$ & 494.2 & 0.0 & 0.5 & 5 & 484.2 \\
\hline $\begin{array}{c}\mathrm{T}+\text { Winter Precip. }+ \text { Active Precip. }+ \\
\text { MMXT + Conceal }\end{array}$ & 495.0 & 0.8 & 0.3 & 6 & 482.9 \\
\hline $\begin{array}{c}\mathrm{T}+\text { Winter Precip. + Active Precip. + } \\
\text { MMXT + Nest Ht. }\end{array}$ & 495.6 & 1.4 & 0.2 & 6 & 483.6 \\
\hline $\mathrm{T}+$ Winter Precip. + Active Precip. & 504.2 & 10.0 & 0.0 & 4 & 496.2 \\
\hline $\mathrm{T}+$ Winter Precip. + MMXT & 505.1 & 10.9 & 0.0 & 4 & 497.1 \\
\hline $\mathrm{T}+$ Winter Precip. & 509.4 & 15.2 & 0.0 & 3 & 503.4 \\
\hline $\mathrm{T}+$ Winter Precip. + BSTEMP & 510.0 & 15.8 & 0.0 & 4 & 502.0 \\
\hline $\mathrm{T}$ & 517.3 & 23.1 & 0.0 & 2 & 513.3 \\
\hline $\mathrm{T}+\mathrm{BSTEMP}$ & 518.1 & 23.8 & 0.0 & 3 & 512.1 \\
\hline TT & 519.3 & 25.0 & 0.0 & 3 & 513.3 \\
\hline Constant & 530.9 & 36.7 & 0.0 & 1 & 528.9 \\
\hline Year & 533.0 & 38.8 & 0.0 & 6 & 521.0 \\
\hline
\end{tabular}


Figure 3. Nest daily survival rates estimated from the highest supported model from program MARK over the course of the breeding period (2007-2012) for Loggerhead shrikes nesting on Kirtland Air Force Base, NM. Day 1 of the nesting season corresponds to March 7, and spanned 147 days for the entire study period. Error bars represent 95\% confidence intervals

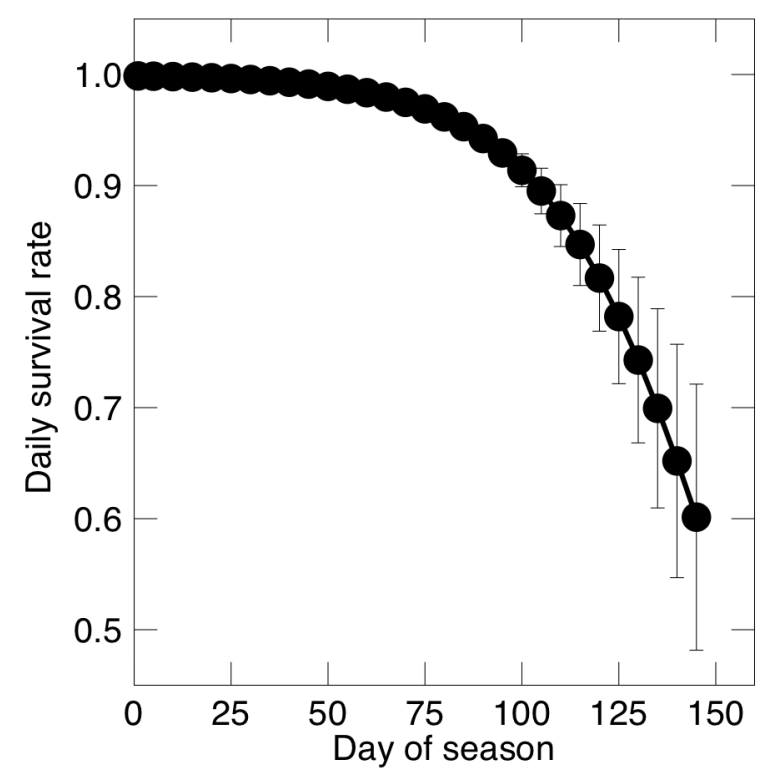

Overall Productivity Metrics

Using multiple linear regressions, we considered the relationship between annual productivity and environmental metrics. Because there is autocorrelation between number of pairs, number of nesting attempts, and estimated eggs laid, we analyzed the number of breeding pairs since this is the primary driver of number of attempts and eggs laid. Total number of pairs was positively related to mean breeding season temperature (Figure 4) and total winter precipitation $\left(R^{2}=0.95, \mathrm{~F}_{2,3}=26.67, P=0.01\right)$ by the following equation: $-79.84+5.59 *$ BSTEMP $+0.08 *$ Winter Precip. Estimated eggs laid was related to BSTEMP only $\left(R^{2}=0.83, \mathrm{~F}_{1,4}=20.16, P=0.01\right)$ by the following equation: $612.5+41.19 *$ BSTEMP. 
Figure 4. Number of breeding Loggerhead shrike pairs between 2007 and 2012 on Kirtland Air Force Base, NM and breeding season temperature $\left({ }^{\circ} \mathrm{C}\right)$.

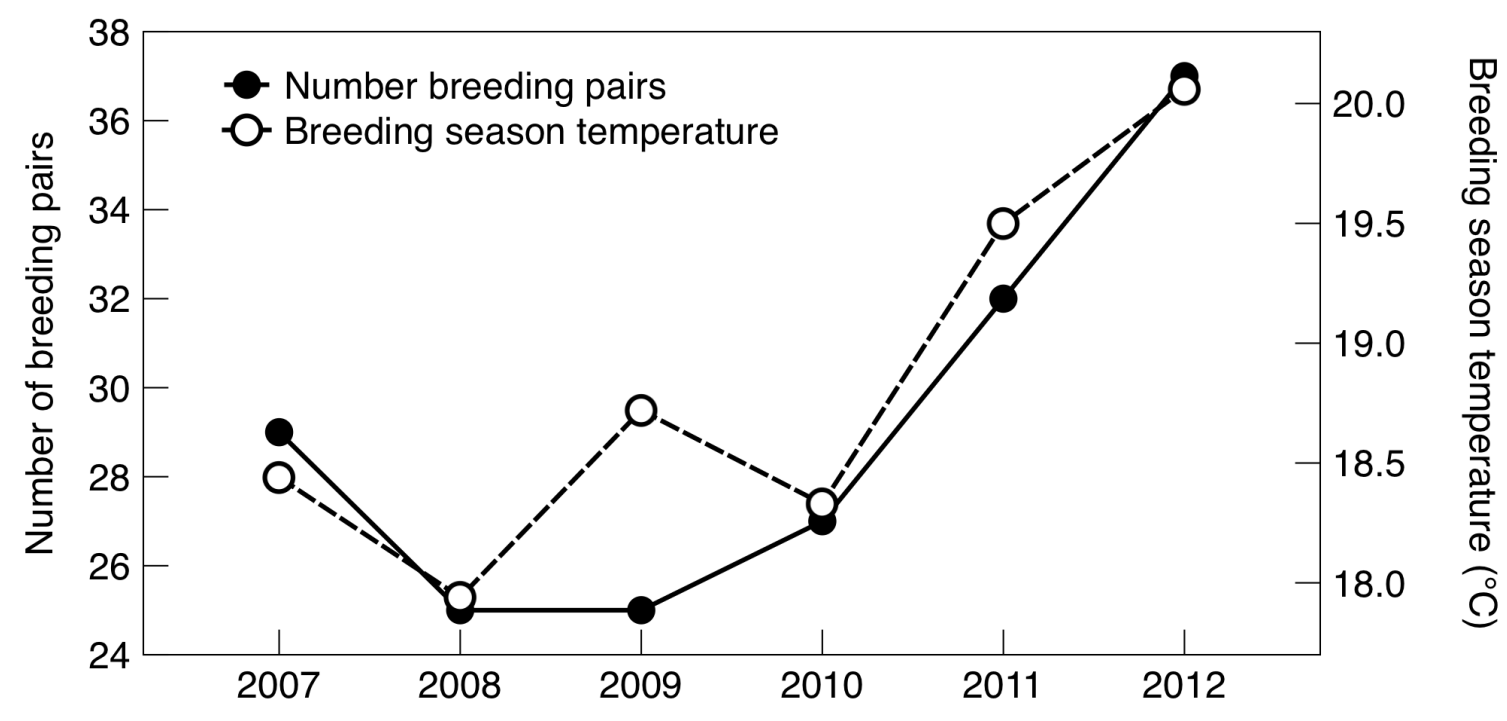

\section{Temperature and Precipitation}

The study area receives an average of $240.54 \mathrm{~mm}$ of precipitation annually, but the mean for the study period was only $188.09 \mathrm{~mm}$ (Table 4). Mean winter precipitation is $51.56 \mathrm{~mm}$, the study period mean was below this at $44.66 \mathrm{~mm}$. Annual precipitation was below the long-term average in all years except 2007, and winter precipitation was below average in all but 2007 and 2012. Mean annual and breeding season temperatures were above the long-term mean in all years of study and showed an overall warming trend over the study period. 
Table 4. Annual and winter precipitation and mean annual and breeding season temperature for Albuquerque International Airport (distance from study area). Winter precipitation was recorded between December of previous year and January - March of year indicated. Breeding season temperatures are the mean of March - July temperatures and spring temperatures are recorded from March - April.

\begin{tabular}{|c|c|c|c|c|c|}
\hline Year & $\begin{array}{l}\text { Annual } \\
\text { Precipitation } \\
(\mathrm{mm})\end{array}$ & $\begin{array}{c}\text { Winter } \\
\text { Precipitation } \\
\text { (Dec. - Mar.) } \\
(\mathrm{mm})\end{array}$ & $\begin{array}{c}\text { Mean Annual } \\
\text { Temperature } \\
\left({ }^{\circ} \mathrm{C}\right)\end{array}$ & $\begin{array}{c}\text { Mean } \\
\text { Breeding } \\
\text { Season } \\
\text { Temp }\left({ }^{\circ} \mathrm{C}\right)\end{array}$ & $\begin{array}{c}\text { Mean } \\
\text { Maximum } \\
\text { Spring } \\
\text { Temp } \\
\left({ }^{\circ} \mathrm{C}\right) \\
\end{array}$ \\
\hline 2007 & 260.1 & 77.0 & 14.4 & 18.4 & 19.3 \\
\hline 2008 & 212.1 & 49.3 & 14.1 & 17.9 & 19.4 \\
\hline 2009 & 169.7 & 24.4 & 14.4 & 18.7 & 19.0 \\
\hline 2010 & 228.1 & 35.1 & 14.6 & 18.3 & 18.1 \\
\hline 2011 & 119.9 & 30.0 & 14.6 & 19.5 & 21.1 \\
\hline 2012 & 138.7 & 52.3 & 15.5 & 20.1 & 21.1 \\
\hline $\begin{array}{l}\text { Study } \\
\text { Period } \\
\text { Mean }\end{array}$ & 188.1 & 44.7 & 14.6 & 18.8 & 19.7 \\
\hline $\begin{array}{l}\text { Mean } \\
(1971- \\
2000)\end{array}$ & 240.5 & 51.6 & 13.8 & 17.9 & 19.2 \\
\hline
\end{tabular}




\section{Discussion}

This study followed a population of breeding loggerhead shrikes over the course of six years during a period of significant warming. During this time we observed dramatic changes in nest phenology, and variation in nest survival that included the lowest reported in the literature for this species. Clutch size and number of young fledged per nest did not change annually, but total number of breeding pairs increased over the course of the study. Each measure that changed was significantly related to environmental variables. In the following paragraphs we discuss each of these observations in detail.

\section{Nest Initiation}

Changes in spring phenology are one of the most commonly observed responses to increasing global temperatures (Parmesan and Yohe 2003; Root et al. 2003; Walther et al. 2002). Most frequently, advancement of spring phenology is correlated to temperatures in the months that immediately precede breeding (Li and Brown 1999; Walther et al. 2002). Over our six-year study period, mean nest initiation dates advanced by 20 days and earliest nests by 28 days (Figure 1), and correlated with increases in mean maximum temperatures during March and April. These findings are similar to those of many other studies, but are unique in the extent of advancement. According to two metaanalyses, the mean advancement of spring activities is 5.1 days per decade (Root et al. 2003 ) or 2.3 days per decade (Parmesan and Yohe 2003), and the most dramatic advancement was 24 days per decade (2.4 days per year), (Root et al. 2003). During this 
study, we observed an advancement of 20 days over 6 years (3.3 days per year), greater than that of any reported species.

Spring mean maximum temperatures increased $3.05^{\circ} \mathrm{C}$ over the study period. This increase did not occur stepwise, but the hottest two years occurred during 2011 and 2012 (Table 4). Considering the global temperature change over the last 100 years is $0.85^{\circ} \mathrm{C}$ (IPCC 2013), the range of temperatures experienced by shrikes during this study period is quite large, as is the degree of variability in nest timing. This illustrates the immediate and drastic effect that temperature change can have on nesting phenology even in isolated years.

The ability of shrikes to advance their spring activities so dramatically can be attributed to a number of factors. While there is evidence of a strong genetic component that drives variability in some species (Schaper et al. 2012), physiological constraints and phenotypic plasticity drives the overall capacity for variation. In this case, the rapid response of nest initiation to temperature suggests that this trait is related to phenotypic plasticity. This plasticity in part may arise from the shrike's large breeding distribution; across their range breeding is initiated between January and May (Collister and Wilson 2007; Yosef 1996). Non-migratory shrike populations showed a large degree of annual variability in nest initiation dates (Hudgens et al. 2009; Yosef 2001), as resident individuals maintain pair bonds during non-breeding months, keeping reproductive cycles synchronized and enabling them to breed when conditions become suitable (Yosef 1996). In this study, some individuals are resident, while others either migrate or disperse away from the site. Earliest nests are most likely nests of these overwintering individuals. However, not only earliest nests, but also mean nest initiation has advanced dramatically, 
suggesting that the entire population is responding to local environmental conditions. Increased temperatures result in reduced energy costs for incubating females (Vleck 1981), and should also increase activity by ectothermic prey items.

\section{Nest Success}

Loggerhead shrikes are often cited as having relatively high nest success for an open-cup breeding passerine (average for all species is 43\%, (Martin 1992). Mean success for loggerhead shrikes in studies prior to 1996 is 56\% (Yosef 1996), and success greater than $70 \%$ has been reported in many studies (Anderson and Duzan 1978; Boal et al. 2003; Brooks and Temple 1990; Chabot et al. 2001). Low success has been reported in a few studies, and is attributed to linear habitats in these cases (Walk et al. 2006; Yosef 1994). Mean success on this study was $31 \%$, and ranged from 12 to $44 \%$; lower than any success previously reported in the literature. This low success likely has strong population consequences, as population growth is limited in part by breeding success (Ezard et al. 2006).

In this study, weather accounted for few cases of direct nest loss, ranging between 0 and $4 \%$ annually, but was never a driving factor in variation of nest success. Similarly, while food limitation can have many demographic impacts on breeding birds (Martin 1987), traits that are typically sensitive to food (e.g., clutch size, numbers of broods, number of offspring fledged) did not vary significantly throughout the study period. Starvation and brood reduction were not common. Thus, while the warmer temperatures and greater drought might impact food, it does not seem to be sufficient to have large effects on reproductive output. 
Predation instead caused the majority of nest failure, and accounted for between 23 and $73 \%$ of nest loss (Table 2). $73 \%$ of nests were lost to predation in 2009 when nest success was only $12 \%$, and only $23 \%$ of nests were lost in 2007 when nest success was highest. We were not, however, able to fully ascertain predation by different sources. Gopher snakes (Pituophis catenifer), coachwhips (Masticophis flagellum) and coyotes (Canis latrans) are present on the study area and are likely the primary nest predators, though this was not quantified. Predator activity and predation rates may be affected by weather or climatic conditions. Temperatures can impact ectotherm (lizard, snake and insect) activity, and snake predation rates are known to increase with temperature in some areas (Cox et al. 2013). Studies suggest that low temperatures and periodic heavy rain limited predator activity and drove differences in annual nest predation rates (Morrison and Bolger 2002). In this study, periods of heavy rainfall were brief and erratic, and it is unlikely that it drove predation rates. Nest survival was higher during the early part of the breeding season (Figure 3), and this could be in part to reduced snake activity during the cooler temperatures experienced at the onset of breeding (Cox et al. 2013; Peterson et al. 1993). However, it does not explain annual variability in nest survival. Predator behavior may be impacted by drought: in dry years predators may focus more on bird nests when their preferential prey sources are less abundant (McShea 2000), and other studies have found higher nest predation rates in dry years (Martin 2007; McShea 2000). Incidental predation that occurs in conjunction with increased search time can also be an important factor in driving nest predation rates (Vickery et al. 1992). Because nests are lost to a variety of predators, individual nest-site characteristics such as nest height or concealment do not have widespread influence on nest survival. Because predators of 
shrike nests are diverse taxonomically and behaviorally, the relationship between environmental conditions and predators is complex. Abundance of alternative prey sources should also impact nest predation rates, and this may be more directly related to precipitation and temperature.

Our results show that both winter and active period precipitation were important in driving nest success (Table 3), and other studies have also shown a positive effect of precipitation on nest success (Collister and Wilson 2007; George et al. 1992; Li and Brown 1999; Monadjem and Bamford 2009; Skagen and Yackel Adams 2012). Primary productivity in arid environments is closely correlated with precipitation (Noy-Meir 1973), and spring primary productivity shows a strong positive relationship with winter precipitation in New Mexico (Muldavin et al. 2008). Food resources, however, do not directly impact nest success. For example, food supplementation of shrikes in California did not affect nest success (Hudgens et al. 2009), though it affected other measures of productivity. It is likely that the positive impact of precipitation on nest success is not directly related to productivity, but rather indirectly through predator abundance or behavior and the availability of alternate prey items for those predators.

Our results also show a positive effect of temperature on nest survival, similar to other studies (Collister and Wilson 2007; Skagen and Yackel Adams 2012). Because shrikes are an early nesting passerine, they are often subject to cold temperatures during the onset of the breeding season. In most studies, higher nest temperatures produced chicks with greater mass, faster feather growth, and increased survival as growing nestlings will invest less total energy to thermoregulation (Dawson et al. 2005). However, when temperatures exceed a certain threshold, fitness costs may be incurred 
(Cunningham et al. 2013). These costs are observed in growing young through reduced mass, size, or delayed fledging (Cunningham et al. 2013), or in increased water loss associated with thermoregulation in the heat (Wolf and Walsberg 1996). A threshold temperature has not been identified for Loggerhead shrikes, but for a similar species, temperatures above $33^{\circ} \mathrm{C}$ resulted in fitness costs. Temperatures exceeded $33^{\circ} \mathrm{C}$ each year during the end of the breeding season (mid-May through July). The majority of breeding activities are completed prior to the onset of high temperatures, but late nests are subject to high temperature stresses. A biologically important temperature threshold may not have been exceeded during this study, or it may have been exceeded but did not affect any measures that we tested. Lower nest survival at the end of the breeding season may have been related to effects of high temperature on shrike fitness or survival, or as discussed above, predator activity.

\section{Number of Breeding Pairs}

Some species may mitigate reproductive efforts during drought conditions through decreased overall nesting attempts (Bolger et al. 2005; Keynan and Yosef 2010). In this study, however, number of breeding pairs and therefore total attempts increased over the study period, and was positively related to mean breeding season temperature and winter precipitation (Figure 4). Decreased precipitation is shown to negatively affect number of nest attempts, and while there is no specific discussion of its' effect on total breeding pairs, we would expect it to affect this measure similarly. In this study, winter precipitation played a minor role in the relationship while breeding season temperatures was the main driving factor. As far as we know, there are no other documentations of 
increased number of pairs or breeding attempts at warmer temperatures. Because number of breeding pairs increased as well as total nest attempts, this cannot be explained simply through an extended season or multiple broods. It is possible that more migrants may have stopped at KAFB, enticed by suitable breeding conditions.

\section{Conclusions}

Temperature had important effects on Loggerhead shrike reproduction. Increases in spring temperatures led to advancement of nest initiation dates, the number of breeding pairs increased along with air temperature and mean maximum temperature played a positive role in driving nest survival. While these effects were generally positive, it is probable that negative effects will be seen if temperatures continue to increase past a certain threshold. High temperatures could have negative fitness effects on adults and juveniles including survival. Indirectly, further increases in temperature could lead to reduced soil moisture translating to reduced primary and secondary productivity. Additionally, it is unclear if advances in nesting phenology will have positive or negative effects on shrike reproduction.

Shrike breeding success hinges primarily on various aspects of precipitation. Winter precipitation was the primary driver of nest survival, and overall precipitation was also important. Loggerhead shrikes have experienced range-wide population declines across a variety of habitat types (Cade and Woods 1997; Pruitt 2000), and temperature has been shown to be and important factor in driving success in northern bird populations (Chabot et al. 2001; Collister and Wilson 2007; Skagen and Yackel Adams 2012), but the relationship between breeding success and precipitation is first described here. As the 
climate in the arid southwestern United States continues to become drier with less reliable winter precipitation, shrike populations in these regions may experience further population declines. Additionally, if higher temperatures attract more breeding birds, but drought conditions lead to high degrees of nest failure, a sink situation could form, potentially leading to local extinctions.

We showed that precipitation was important in determining nest success, however, the specific pathway of this relationship is undefined. While rainfall is positively correlated with primary productivity, resulting in increased food resources, shrike productivity measures that are immediately impacted by this did not change. Therefore, indirect effects of precipitation such as predator behavior, abundance, and the abundance of alternative prey sources must play an important role in limiting this system. The relationship between drought conditions and predator behavior warrants further study. Arid lands in North America are anticipated to become much more extreme environments over the coming century. Understanding not only the direct effects of these changes, but complex community interactions will be paramount in managing these areas in the future. 


\section{References}

Akaike H (1973) Information theory and an extension of the maximum likelihood principle. In: Petran BN, Csaki F (eds) International symposium on information theory, Second edn. Akademiai Kiado, Budapest, Hungary, pp 267-281

Anderson DR, Burnham KP, White GC (1998) Comparison of Akaike information criterion and consistent Akaike information criterion for model selection and statistical inference from capture-recapture studies. Journal of Applied Statistics 25:263-282

Anderson WL, Duzan RE (1978) DDE residues and eggshell thinning in Loggerhead Shrikes. Wilson Bull. 90:215-220

Arnold TW (2010) Uninformative parameters and model selection using Akaike's information criterion. J. Wildl. Manage. 74:1175-1178. doi: 10.2193/2009-367

Boal CW, Estabrook TS, Duerr AE (2003) Productivity and breeding habitat of loggerhead shrikes in a southwestern urban environment. Southwest. Nat. 48:557562. doi: 10.1894/0038-4909(2003)048<0557:pabhol $>2.0$.co;2

Bolger DT, Patten MA, Bostock DC (2005) Avian reproductive failure in response to an extreme climatic event. Oecologia 142:398-406. doi: 10.1007/s00442-004-1734-9

Both C, Bouwhuis S, Lessells CM, Visser ME (2006) Climate change and population declines in a long-distance migratory bird. Nature 441:81-83. doi: 10.1038 /nature04539

Brooks BL, Temple SA (1990) Dynamics of a Loggerhead Shrike population in Minnesota. Wilson Bull. 102:441-450

Brown JL, Li SH, Bhagabati N (1999) Long-term trend toward earlier breeding in an American bird: a response to global warming? Proceedings of the National Academy of Sciences of the United States of America 96:5565-5569

Cade TJ, Woods CP (1997) Changes in distribution and abundance of the Loggerhead Shrike. Conserv. Biol. 11:21-31. doi: 10.1046/j.1523-1739.1997.95279.x

Chabot AA, Bird DM, Titman RD (2001) Breeding biology and nesting success of Loggerhead Shrikes in Ontario. Wilson Bull. 113:285-289. doi: 10.1676/00435643(2001)113[0285:bbanso]2.0.co;2

Charmantier A, McCleery RH, Cole LR, Perrins C, Kruuk LEB, Sheldon BC (2008) Adaptive phenotypic plasticity in response to climate change in a wild bird population. Science 320:800-803. doi: 10.1126/science. 1157174 
Collister DM, Wilson S (2007) Contributions of Weather and Predation to Reduced Breeding Success in a Threatened Northern Loggerhead Shrike Population. Avian Conservation and Ecology 2:12

Cox WA, Thompson FR, Reidy JL (2013) The effects of temperature on nest predation by mammals, birds, and snakes. Auk 130:784-790. doi: 10.1525/auk.2013.13033

Cunningham SJ, Kruger AC, Nxumalo MP, Hockey PAR (2013) Identifying Biologically Meaningful Hot-Weather Events Using Threshold Temperatures That Affect LifeHistory. Plos One 8:11. doi: 10.1371/journal.pone.0082492

Dawson RD, Lawrie CC, O'Brien EL (2005) The importance of microclimate variation in determining size, growth and survival of avian offspring: experimental evidence from a cavity nesting passerine. Oecologia 144:499-507. doi: 10.1007/s00442005-0075-7

Dick-Peddie WA (1993) New Mexico Vegetation: Past, Present, and Future. University of New Mexico Press, Albuquerque, NM

Dunn PO, Winkler DW, Whittingham LA, Hannon SJ, Robertson RJ (2011) A test of the mismatch hypothesis: How is timing of reproduction related to food abundance in an aerial insectivore? Ecology 92:450-461. doi: 10.1890/10-0478.1

Ezard THG, Becker PH, Coulson T (2006) The contributions of age and sex to variation in common tern population growth rate. J. Anim. Ecol. 75:1379-1386. doi: 10.1111/j.1365-2656.2006.01162.x

George TL, Fowler AC, Knight RL, McEwen LC (1992) Impacts of a severe drought on grassland birds in western North Dakota. Ecol. Appl. 2:275-284. doi: $10.2307 / 1941861$

Hudgens BR, Johnson NN, Bradley JE, Bridges AS (2009) Benefits of supplemental feeding are climate dependent in the San Clemente Loggerhead Shrike. In: Damiani CC, Garcelon DK (eds) Proceedings of the 7th California Islands Symposium. Institute for Wildlife Studies, Arcata, CA, pp 315-325

IPCC (2013) Summary for Policymakers. In: Stocker TF, D. Qin, G. -K. Plattner, M. Tignor, S. K. Allen, J. Boschung, A. Nauels, Y. Xia, V. Bex, and P. M. Midgley (ed) Climate Change 2013: The Physical Science Basis. Contribution of Working Group I to the Fifth Assessment Report of the Intergovernmental Panel on Climate Change. Cambridge University Press, Cambridge, United Kingdom. and New York, NY, USA

Jehle G, Adams AAY, Savidge JA, Skagen SK (2004) Nest survival estimation: A review of alternatives to the Mayfield estimator. Condor 106:472-484. doi: 10.1650/7411 
Keynan O, Yosef R (2010) Annual precipitation affects reproduction of the Southern Grey Shrike (Lanius meridionalis) Wilson Journal of Ornithology 122:334-339. doi: 10.1676/09-148.1

Li SH, Brown JL (1999) Influence of climate on reproductive success in Mexican Jays. Auk 116:924-936

Martin TE (1987) Food as a limit on breeding birds: a life history perspective. Annu. Rev. Ecol. Syst. 18:453-487. doi: 10.1146/annurev.ecolsys.18.1.453

Martin TE (1992) Breeding productivity considerations: What are the appropriate habitat features for management? In: Hagan JM, III, Johnston DW (eds) Ecology and Conservation of Neotropical Migrant Landbirds. Smithsonian Institution Press, pp $455-473$

Martin TE (2007) Climate correlates of 20 years of trophic changes in a high-elevation riparian system. Ecology 88:367-380. doi: 10.1890/00129658(2007)88[367:ccoyot $] 2.0 . c o ; 2$

Martin TE, Roper JJ (1988) Nest predation and nest-site selection of a western population of the Hermit Thrush. Condor 90:51-57. doi: 10.2307/1368432

Mayfield HF (1961) Nesting success calculated from exposure. Wilson Bull. 73:255-261

Mayfield HF (1975) Suggestions for calculating nest success. Wilson Bull. 87:456-466

McKechnie AE, Wolf BO (2010) Climate change increases the likelihood of catastrophic avian mortality events during extreme heat waves. Biol. Lett. 6:253-256. doi: $10.1098 / \mathrm{rsbl} .2009 .0702$

McShea WJ (2000) The influence of acorn crops on annual variation in rodent and bird populations. Ecology 81:228-238. doi: 10.1890/00129658(2000)081[0228:tioaco]2.0.co;2

Monadjem A, Bamford AJ (2009) Influence of rainfall on timing and success of reproduction in Marabou Storks Leptoptilos crumeniferus. Ibis 151:344-351. doi: 10.1111/j.1474-919X.2009.00912.x

Morrison SA, Bolger DT (2002) Variation in a sparrow's reproductive success with rainfall: food and predator-mediated processes. Oecologia 133:315-324. doi: $10.1007 / \mathrm{s} 00442-002-1040-3$

Muldavin EH, Moore DI, Collins SL, Wetherill KR, Lightfoot DC (2008) Aboveground net primary production dynamics in a northern Chihuahuan Desert ecosystem. Oecologia 155:123-132. doi: 10.1007/s00442-007-0880-2 
Noy-Meir I (1973) Desert Ecosystems: Environment and Producers. Annu. Rev. Ecol. Syst. 4:25-51

Parmesan C, Yohe G (2003) A globally coherent fingerprint of climate change impacts across natural systems. Nature 421:37-42. doi: 10.1038/nature01286

Peterson CL, Gibson AR, Dorcas ME (1993) Snake thermal ecology: the causes and consequences of body-temperature variation. In: Seigal RA, Collins JT (eds) Snakes: ecology and behavior. McGraw-Hill, New York, NY, pp 241-314

Porter DK, Strong MA, Giezentanner JB, Ryder RA (1975) Nest ecology, productivity, and growth of the Loggerhead Shrike on the shortgrass prairie. The Southwestern Naturalist:429-436

Pruitt L (2000) Loggerhead Shrike Status Assessment. United States Fish and Wildlife Services, Bloomington, IN, p 176

R Core Team (2013) R: A language and environment for statistical computing. In: R Foundation for Statistical Computing (ed), Vienna, Austria

Romero-Lankao P et al. (2014) Climate Change 2014: Impacts, Adaptation, and Vulnerability. Part B. Regional Aspects. Contribution of Working Group II to the Fifth Assessment Report of the Intergovernmental Panel on Climate Change. In: Barros VR, Field CB, Dokken DJ, Mastrandrea MD, Mach KJ, Bilir TE, Chatterjee M, Ebi KL, Estrada YO, Genova RC, Girma B, Kissel ES, Levy AN, MacCracken S, Mastrandrea PR, White LL (eds), Cambridge, United Kingdom and New York, NY, USA

Root TL, Price JT, Hall KR, Schneider SH, Rosenzweig C, Pounds JA (2003) Fingerprints of global warming on wild animals and plants. Nature 421:57-60. doi: $10.1038 /$ nature 01333

Rotella JJ, Taper ML, Hansen AJ (2000) Correcting nesting-success estimates for observer effects: Maximum-likelihood estimates of daily survival rates with reduced bias. Auk 117:92-109. doi: 10.1642/00048038(2000)117[0092:cnsefo]2.0.co;2

Saino N et al. (2011) Climate warming, ecological mismatch at arrival and population decline in migratory birds. Proc. R. Soc. B-Biol. Sci. 278:835-842. doi: $10.1098 /$ rspb.2010.1778

Sauer JR, Hines JE, Fallon JE, Pardieck KL, Ziolkowski DJJ, Link WA (2014) The North American Breeding Bird Survey, Results and Analysis 1966 - 2012. Version 02.19.2014. USGS Patuxent Wildlife Research Center, Laurel, MD 
Schaper SV, Dawson A, Sharp PJ, Gienapp P, Caro SP, Visser ME (2012) Increasing Temperature, Not Mean Temperature, Is a Cue for Avian Timing of Reproduction. Am. Nat. 179:E55-E69. doi: 10.1086/663675

Skagen SK, Yackel Adams AA (2012) Weather effects on avian breeding performance and implications of climate change. Ecol. Appl. 22:1131-1145

State of New Mexico (2005) Potential effects of climate change on New Mexico. Agency Technical Work Group, State of New Mexico

Tanaka LK, Tanaka SK (1982) Rainfall and seasonal-changes in arthropod abundance on a tropical oceanic island. Biotropica 14:114-123. doi: 10.2307/2387740

Vickery PD, Hunter ML, Wells JV (1992) Evidence of incidental nest predation and its effects on nests of threatened grassland birds. Oikos 63:281-288. doi: $10.2307 / 3545389$

Vleck CM (1981) Energetic cost of incubation in the Zebra Finch. Condor 83:229-237. doi: $10.2307 / 1367313$

Walk JW, Kershner EL, Warner RE (2006) Low nesting success of Loggerhead Shrikes in an agricultural landscape. Wilson Journal of Ornithology 118:70-74. doi: 10.1676/1559-4491(2006)118[0070:Insols]2.0.co;2

Walther GR et al. (2002) Ecological responses to recent climate change. Nature 416:389395. doi: $10.1038 / 416389 a$

White GC, Burnham KP (1999) Program MARK: survival estimation from populations of marked animals. Bird Study 46:120-139

Wolf BO, Walsberg GE (1996) Respiratory and cutaneous evaporative water loss at high environmental temperatures in a small bird. J. Exp. Biol. 199:451-457

Yosef R (1994) The effects of fencelines on the reproductive success of Loggerhead Shrikes. Conserv. Biol. 8:281-285. doi: 10.1046/j.1523-1739.1994.08010281.x

Yosef R (1996) Loggerhead Shrikes (Lanius ludovicianus). . In: Poole A, Gill F (eds) The Birds of North America, vol 231. The Academy of Natural Sciences and the American Ornithologists' Union, Philadelphia, PA

Yosef R (2001) Nesting ecology of resident Loggerhead Shrikes in southcentral Florida. Wilson Bull. 113:279-284. doi: 10.1676/00435643(2001)113[0279:neorls]2.0.co;2 